\title{
PERANCANGAN PORTAL $E$-LEARNING MENGGUNAKAN DRUPAL CMS SEBAGAI PENUNJANG PERKULIAHAN PADA MASA PANDEMI COVID-19
}

\author{
Selli Mariko \\ Universitas Indraparasta PGRI \\ Jakarta Selatan, Indonesia \\ sellimariko85@gmail.com
}

\begin{abstract}
Abstrak
Awal tahun 2020 Indonesia dan dunia menghadapi sebuah krisis global karena pandemi virus corona atau Covid-19. Dunia pendidikan tidak luput merasakan dampak akibat wabah virus Covid-19 yaitu dengan diberlakukan semi lockdown oleh pemerintah. Oleh karena itu, seluruh kegiatan yang sifatnya mengumpulkan orang banyak dilarang oleh pemerintah. Keadaan ini tidak memungkinkan untuk dosen melakukan kewajibannya terkait dengan tridharma. Dosen tidak diperkenankan mengikuti kegiatan ilmiah seperti seminar nasional, diskusi panel maupun forum ilmiah lainnya. Keadaan yang paling parah adalah kegiatan perkuliahan tatap muka di kelas yang ditiadakan selama hampir satu semester. Tujuan dari penulisan artikel ini adalah untuk mengatasi permasalahan yang dihadapi oleh dosen dalam mengganti kegiatan perkuliahan tatap muka di kelas. Solusi yang ditawarkan penulis dalam artikel ini adalah membuat portal e-Learning yang dibangun menggunakan Drupal CMS. Perangkat teknologi ini memungkinkan interaksi antara dosen dan mahasiswa tanpa batasan ruang dan waktu. Metode penelitian dan pengembangan sistem yang digunakan System Development Life Cycle (SDLC) yang dikembangkan dengan metode prototyping. Adapun manfaat dari hasil penelitian ini adalah: 1. Dosen dapat menuntaskan materi perkuliahan; 2. Mahasiswa dapat mengakses materi dan mendapatkan feedback secara langsung dari dosen; 3. Dosen dapat melakukan penilaian melalui instrumen tes secara online dan mengumpulkan tugas mahasiswa.
\end{abstract}

\section{Kata Kunci: Portal e-Learning, Drupal CMS, Pandemi Covid-19}

\begin{abstract}
Beginning in 2020 Indonesia and the world face a global crisis due to the corona virus or pandemi Covid19. The education has not been spared the effects of the Covid-19 virus outbreak, which is the introduction of a semi-lock down by the government. Therefore, all activities that gather people are prohibited by the government.This situation makes it impossible for lecturers to carry out their obligations related to tridharma. Lecturers are not permitted to participate in scientific activities such as national seminars, panel discussions or other scientific forums.The most severe situation is the face-to-face lecture activities in the classroom which were held for almost one semester.The purpose of writing this article is to overcome the problems faced by lecturers in replacing face-to-face lecture activities in class.The purpose of writing this article is to overcome the problems faced by lecturers in replacing face-to-face lecture activities in class. The solution offered by the author in this article is to create an e-Learning portal that was built using Drupal CMS. This technological device enables interaction between lecturers and students without space and time restrictions. The system research and development method used is the System Development Life Cycle (SDLC) which was developed using the prototyping method.The benefits of this research are: 1 . Lecturers can complete lecture material; 2. Students can access the material and get feedback directly from the lecturer; 3. Lecturers can make assessments through online test instruments and collect student assignments.
\end{abstract}

Keywords: e-Learning Portal, Drupal CMS, Pandemi Covid-19 


\section{PENDAHULUAN}

Virus corona atau Covid-19 yang menyebar pada manusia begitu cepat memaksa Pemerintah untuk mengeluarkan kebijakan lockdown dalam rangka memutus penyebaran virus corona. Hal ini berimbas pada aktivitas semua lapisan/elemen masyarakat tidak terkecuali dengan masalah pendidikan. Adanya aturan pemerintah tersebut berdampak pada aktivitas perkuliahan yang ditiadakan selama hampir satu semester. Beberapa kampus sudah menyiasati keadaan tersebut dengan memberikan perkuliahan pengganti secara online menggunakan berbagai jenis Content Management System (CMS). Bahkan ada beberapa kampus yang sudah merancang CMS dengan membangun portal $e$ Learning sebelum terjadinya wabah Covid19. Akan tetapi jumlah institusi yang siap menggunakan sistem ini jumlahnya tidaklah banyak. Hal ini dikarenakan jumlah Sumber Daya Manusia (SDM) pada institusi yang memiliki pengetahuan dalam bidang ini masih terbatas.

Permasalahan lainnya yang muncul adalah dosen dituntut untuk menuntaskan materi perkuliahan ditengah pandemic Covid-19. Padahal aturan pemerintah sudah jelas untuk meliburkan semua aktivitas kegiatan pembelajaran mulai dari tingkat dasar, tingkat menengah sampai perguruan tinggi. Hal ini menjadi tantangan khususnya bagi seorang dosen untuk menuntaskan materi perkuliahan. Apabila materi perkuliahan tidak dapat disampaikan kepada mahasiswa maka dosen tidak dapat mengukur kompetensi dari mahasiswa. Selain itu dosen juga tidak dapat memberikan penugasan karena mahasiswa tidak mengetahui apa yang mereka pelajari.
Selain itu dosen wajib memberikan penilaian kepada mahasiswa di pertengahan dan akhir semester. Penilaian digunakan untuk mengukur kompetensi mahasiswa dalam menguasai materi perkuliahan. Akan tetapi perkuliahan tatap muka di kelas diliburkan selama hampir satu semester. Hal ini sangat menyulitkan bagi dosen dalam memberikan penilaian kepada mahasiswa. Ditiadakannya perkuliahan di kelas dapat menghambat penyampaian materi perkuliahan. Selain itu, pengukuran kompetensi juga menjadi tidak valid/ tidak dapat dipertanggungjawabkan. Dosen tidak mungkin memberikan penilaian kepada mahasiswa secara asal tanpa melihat kapabilitas dan kompetensi mahasiswa.

Kewajiban utama dosen lainnya yaitu tetap melakukan tridharma di tengah pandemi Covid-19. Hal ini akan lebih menyita waktu yang mengakibatkan dosen tidak dapat berinteraksi dengan mahasiswa. Misalkan seorang dosen harus melakukan pengambilan dan uji sampel penelitian sampai ke luar daerah. Secara otomatis dosen meninggalkan kegiatan perkuliahan walaupun kuliah tidak diliburkan. Oleh karena itu sangat diperlukan sekali sebuah solusi yang dapat menyelesaikan berbagai permasalahan dosen diwaktu pandemi Covid-19.

Oleh karena itu tujuan utama dari penelitian ini adalah dosen maupun institusi dapat membuat CMS dalam bentuk sebuah portal e-Learning menggunakan Drupal CMS. Portal ini dapat menjadi sebuah solusi bagi dosen dan mahasiswa untuk dapat berinteraksi tanpa ada batasan ruang dan waktu. Walaupun kegiatan perkuliahan tatap muka diliburkan, dosen tetap dapat memberikan materi dengan mengunggah materi dalam format digital pada portal $e$ - 
Learning. Selanjutnya mahasiswa diwajibkan untuk mengunduh materi dan mempelajari yang diunggah oleh dosen. Apabila ada pertanyaan dari mahasiswa maka dapat disampaikan melalui fitur messaging pada portal kemudian dosen memberikan feedback secara langsung.

Ada beberapa manfaat dari hasil penelitian tentang perancangan sistem perkuliahan dengan e-Learning. Pertama, dosen dapat menyampaikan materi perkuliahan sampai tuntas. Kedua, dosen dapat memberikan feedback kepada mahasiswa secara langsung apabila mahasiswa menemui kendala dalam memahami materi. Ketiga, dosen dapat mengukur kompetensi mahasiswa dengan memberikan tugas dan penilaian secara online.

Pada era digital memungkinkan dosen dan institut pendidikan seharusnya dengan cepat mengatasi masalah perkuliahan dengan adanya aturan lockdown dari pemerintah. Saat ini banyak sekali perangkat teknologi yang dapat digunakan untuk perkuliahan online dengan mengunggah materi dalam bentuk elektronik atau digital. Hal ini sesuai dengan hasil penelitian sebelumnya yang dilakukan oleh Prawiradilaga dkk (2016:17) bahwa teknologi informasi dan komunikasi (TIK) adalah media interaktif yang digunakan untuk berkomunikasi jarak jauh dalam rangka tukar menukar informasi. Pada perkembangan berikutnya TIK lebih dikenal dengan istilah "Media Komputer" yang digunakan sebagai media perkuliahan, baik itu bersifat luring maupun daring. Komputer sebagai media perkuliahan secara bergantian disebut dengan multimedia. Kemampuan teknologi yang dimiliki "komputer" menjadi sarana yang sangat efektif dan efisien untuk digunakan sebagai modalitas dalam perkuliahan. Inilah yang menjadikan teknologi komputer memberi banyak ragam dalam perkuliahan khususnya teknologi tersebut terhubung dengan jaringan internet. Berbagai ragam perkuliahan berbasis komputer bermunculan, yaitu: 1. Computer Based Learning (CBL); 2. Online Learning atau Web Based Learning; 3. e-Learning/ distance Learning.

CMS merupakan sistem aplikasi untuk membuat sebuah portal pada halaman website. CMS dengan konsep mengelola sebuah coursel perkuliahan lebih dikenal dengan nama Learning Management System (LMS), dimana LMS dapat menyediakan dan mengirimkan konten materi perkuliahan serta dapat melacak aktivitas mahasiswa melalui daring. Selain itu mahasiswa juga dapat mengirimkan tugas, mengerjakan kuis dan mendapat feedback dari dosen menggunakan fitur messaging ataupun chat. Hal ini senada dengan apa yang disampaikan oleh Courts \& Tucker (2012: 125) “ In addition, learning management systems, such as BlackBoard and eCollege, have mobile applications, like BlackBoard Mobile, which allows students and instructors to access their online classes via their Smartphone. Instructors can post announcements, grade assignments, check on course activity, and participate in class discussions. Students can submit their work, read and respond to discussion questions, and take quizzes all via their Smartphone". Penggunaan CMS menawarkan inovasi baru dalam sebuah perkuliahan dengan memanfaatkan perangkat teknologi informasi yaitu dengan memanfaatkan open source yang dapat diunduh secara gratis 
melalui website resmi. Pada penelitian ini penulis menggunakan Drupal CMS untuk membangun portal $e$-Learning. Apabila kita ingin membangun secara offline atau master aplikasi tidak disediakan pada softacoulus untuk membangun portal secara online maka master aplikasi dapat diunduh melalui website resmi Drupal CMS dengan alamat https://www.drupal.org/download.

Sistem perkuliahan dengan menggunakan portal e-Learning dapat terjadi tanpa dosen bertemu/ tatap muka dengan mahasiswa. Oleh karena itu beberapa ahli mengatakan sistem perkuliahan ini dengan istilah lainnya yaitu blended learning. Beberapa ahli memberikan arti atau definisi tentang blended learning. Menururt Horton (2006:381) memberikan definisi bahwa "Blended learning can be define simply as the mixture of different forms of education or training for a single purpose. The only thing remarkable abaout this definition is that it does not limit itself to mixtures of eLearning and classroom learning. A blend can be any mixture of any form of learning possible: classroom, virtual-classroom, or stand alone e-Learning". Selain itu definisi lain blended learning menurut Littlejohn \& Pegler (2007:9) "blended learning is: 1. Acces to a wide choice of alternative resources on your personal computer. 2. Creation within a course that is rich in online collaboration. 3. Downloading content to mobile devices. 4. Immersion in online multi-player gaming or multimedia role-playing using extended, authentic simulation. 5. Personalized content delivered through a customized interface flag new content relevant to individual interests. 6. Using virtual learning environment (VLE) to access course materials and ask questions wether on-oroff-campus. 7. Uploading notes to your own blog (weblog) while the lecture is in progress and using hand-held voting devices to offer instant feedback to the presenter. 8. Learning on a just-in-time basis using computer based tutorials. 9. Staying in contact with study buddies away from the class through use of instant messaging and informal "social computing". 10. Assembling and publishing your work from courses studied across several institutions. 11. Virtual learning spaces that integrate and accommodate technology, but focus on student learning. 12. Succesful and rewarding studentteacher relationships initiated and maintained through online communication without ever meeting face to face."

Selain untuk mengatasi permasalahan kegiatan perkuliahan yang dihadapi oleh dosen dalam masa pandemi Covid-19, sistem perkuliahan dengan menggunakan konsep CMS dapat menjadi trending dan wahana perkuliahan yang baru. Hal ini dikarenakan portal e-Learning menggunakan berbagai fitur yang memudahkan interaksi antara dosen dan mahasiswa. Mahasiswa dapat mengunduh berbagai konten materi yang tidak terbatas dan keuntungan lainnya adalah biaya operasional yang murah. Hal ini diperkuat dari hasil penelitian yang publish pada sebuah jurnal oleh Khazaal, H.F. et all. (2014: 132) "e-Learning is the new trend in education. It is used by innumerable educational, industrial, and continuing education organizations worldwide. Among the many advantages of e-Learning is the reduction of time and money devoted to the education enterprise. Ongoing research to strengthen this approach to education and 
to widen its implementation is of vital importance".

\section{METODE PENELITIAN}

Jenis penelitian yang dilakukan oleh peneliti untuk merancang CMS menggunakan open source Drupal CMS adalah Research and Development ( $\& \& D)$. Sama halnya dengan pengembangan sistem aplikasi lainnya metode yang digunakan adalah System Development Life Cycle (SDLC). Namun metode ini dikembangkan lebih jauh lagi menggunakan metode prototyping. Fatta (2007: 36) Metode prototyping adalah proses iterative dalam pengembangan sistem dimana kebutuhan diubah ke dalam sistem yang bekerja (working system) yang secara terus menerus diperbaiki melalui kerjasama antara pengguna dan analis. Prototype dapat dibangun melalui beberapa tool untuk menyederhanakan proses. Prototyping merupakan bentuk dari Rapid Application Development (RAD).

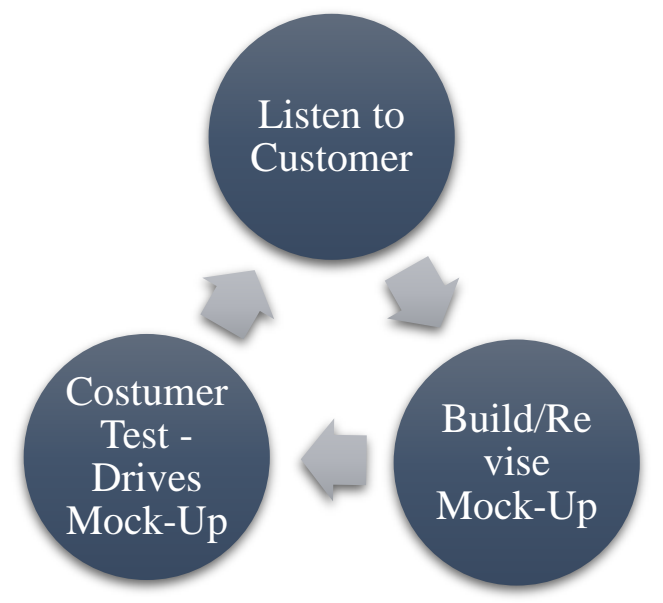

Gambar 1. Metode pengembangan prototyping

Gambar 1. menunjukkan diagram metode pengembangan prototyping, sedangkan alur/ tahapan yang dilakukan pada metodologi pengembangan sistem prototype adalah sebagai berikut:

1. Analis bekerja dengan tim perancang sistem untuk identifikasi kebutuhan awal sistem.

2. Analisis kemudian membangun prototype. Ketika sebuah prototype sudah selesai maka user bekerja dengan prototype tersebut kemudian menyampaikan kepada analis.

3. Analis kemudian menggunakan feedback untuk memperbaiki prototype.

4. Sistem yang baru kembali dikirim dan digunakan oleh user.

5. Mengulangi langkah dari awal sampai user merasa puas.

Adapun keuntungan pengembangan sistem dengan metode prototype:

1. Prototype melibatkan user dalam proses analisis dan desain produk.

2. Memiliki kemampuan menangkap kebutuhan user secara konkret.

3. Dapat digunakan secara standalone.

4. Digunakan untuk memperluas System Development Life Cycle (SDLC).

Setelah prototype yang berupa portal e-Learning dirancang, maka sesuai metode penelitian yang digunakan untuk langkah selanjutnya adalah analisis sistem dengan melibatkan user/ mahasiswa. Pengambilan sample dari user/ mahasiswa dipilih secara random sampling sebanyak 30 mahasiswa. Pada tahap ini dianalisis tentang aksesibilitas sistem, kebermanfaatan sistem dan motivasi belajar dengan sistem. Untuk melihat hasil analisis maka kita akan merubah data kuantitatif menjadi data kuliatatif dalam bentuk cluster. Menurut Jaya (2019:5) data kualitatif adalah data yang berbentuk kategorisasi, karakteristik berbentuk kalimat, kata - kata atau gambar. Data kualitatif merupakan data yang menunjukkan kualitas sesuatu, oleh karena itu data kualitatif sering menunjukkan 
kualitas sesuatu baik manusia, benda maupun suatu variabel tertentu seperti motivasi, minat dan lain sebagainya.

Tabel 1.Konversi data kuantitatif menjadi data kualitatif

\begin{tabular}{cc}
\hline Persyaratan & Klasifikasi \\
\hline$X>($ Mean + Std. Dev $)$ & Tinggi \\
$X<($ Mean + Std. Dev $)$ & Rendah \\
\hline
\end{tabular}

$$
\begin{gathered}
\text { Mean }=\frac{\sum_{i=1}^{i=n} X_{i}}{\sum n} \\
\text { Std.Dev }=\sqrt{\frac{\sum_{i=1}^{i=n}\left(X_{i}-\text { Mean }\right)^{2}}{n-1}}
\end{gathered}
$$

Di mana:

$\begin{array}{ll}\text { Mean } & \text { : Nilai rata - rata } \\ n & \text { : Jumlah sampel } \\ \text { Std.Dev } & \text { : Nllai standar deviasi } \\ X_{i} \quad \text { Untuk } & \text { : Nilai sampel ke i } \\ & \text { melakukan konversi data }\end{array}$
kuantitatif menjadi kualitatif maka persyaratan yang digunakan dapat mengacu pada Tabel 1. Klasifikasi data kualitatif disusun dengan memberikan kategori terhadap kuantitas tertentu kita dapat mengubah data kuantitatif menjadi kualitatif.

\section{HASIL PENELITIAN DAN PEMBAHASAN}

Mengacu pada tujuan penelitian yaitu mengatasi berbagai permasalahan yang terjadi atas ditiadakannya perkuliahan tatap muka di kelas karena pandemi Covid -19, maka solusi yang ditawarkan oleh peneliti adalah membuat Content Management System (CMS) yang berisi materi perkuliahan dalam bentuk portal $e$ Learning. Adanya portal e-Learning memungkinkan mahasiswa dan dosen tetap dapat berkomunikasi untuk memberikan materi, diskusi dan pengumpulan tugas. Hal in senada dengan hasil riset Shandyastini \& Novianti (2016:5) yang menjelaskan bahwa mahasiswa mendapatkan banyak manfaat ketika menggunakan e-Learning STMIK SIKOM Bali untuk menunjang proses perkuliahan mereka. Melalui penggunaan $e$ learning mahasiswa dapat mendapatkan akses terhadap materi perkuliahan dari dosen pengajar, daftar tugas, daftar quiz, serta pengumuman tambahan tentang akademik. Selain itu mereka dapat berinteraksi dengan sesama mahasiswa maupun dosen melalui forum diskusi ilmiah. Penelitian ini menggunakan Drupal CMS untuk membangun portal e-Learning.

Drupal CMS merupakan open source untuk membuat sebuah Content Management System (CMS) yang berfungsi untuk membuat content pada halaman website.Konten CMS yang berisikan materi digital untuk pembelajaran/ perkuliahan yang lebih familiar dengan istilah Learning Management System (LMS). Fitur yang terdapat dalam CMS ini berisikan: 1. Materi perkuliahan dalam bentuk digital; 2. Link atau tautan yang berisi pendukung perkuliahan; 3. Forum untuk melakukan diskusi dan memberikan feedback secara online. Drupal CMS merupakan perangkat lunak(software) yang terdistribusi di bawah lisensi General Public License (GPL).

Untuk melakukan instalasi/ pemasangan CMS dengan Drupal CMS dapat dilakukan secara offline maupun online. Untuk membuat CMS secara offline maka Drupal membutuhkan sebuah webserver, sedangkan jika membangun CMS secara online maka harus disediakan web hosting. Dikarenakan CMS ini nantinya akan digunakan untuk mendukung 
perkuliahan selama masa Pandemi Covid19 maka penulis akan membangun CMS ini secara online. Untuk membangun portal $e$ Learning dengan Drupal CMS secara online maka alur/ tahapan dapat dilihat pada Gambar 2.

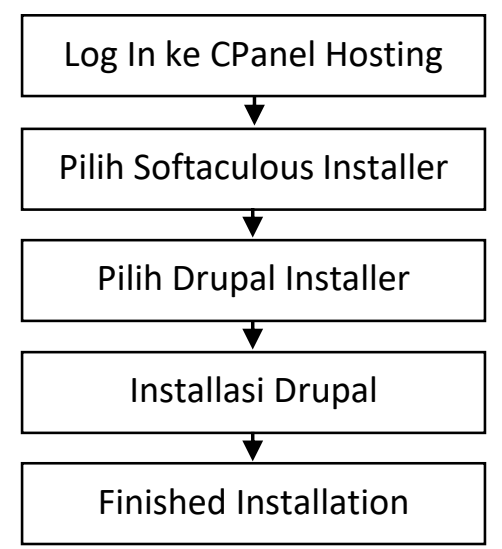

Gambar 2. Tahap membangun Drupal CMS secara online

Perancangan portal e-Learning dengan menggunakan Drupal CMS ada beberapa langkah yang ditempuh seperti pada Gambar 2. Berikut ini dijelaskan tahapan pengembangan CMS secara online pada web hosting:

1. Login ke dalam cPanel pada web hosting dengan menggunakan web browser. Ketikan alamat yang kita akses adalah: https://namadomain/cpanel.

2. Pada halaman cPanel kita mencari menu "softaculous" kemudian pilih "softaculous Apps Installer".

3. Pada halaman dashboard Softaculous, dapat dilihat berbagai macam Content Management System (CMS) yang dapat dipasang. Pilih Drupal untuk membangun CMS dengan Drupal.

4. Pada halaman Drupal di Softaculous dapat dilihat beberapa fitur Drupal, screenshots, review dan sebagainya. Selain itu pada halaman ini kita dapat memilih versi Drupal yang diinginkan. Terakhir klik "Install Now" untuk melakukan proses instalasi.
5. Setelah sukses proses pemasangan Drupal maka pada tahap akhir dapat dilakukan pengaturan pada beberapa konfigurasi khususnya untuk akun admin.

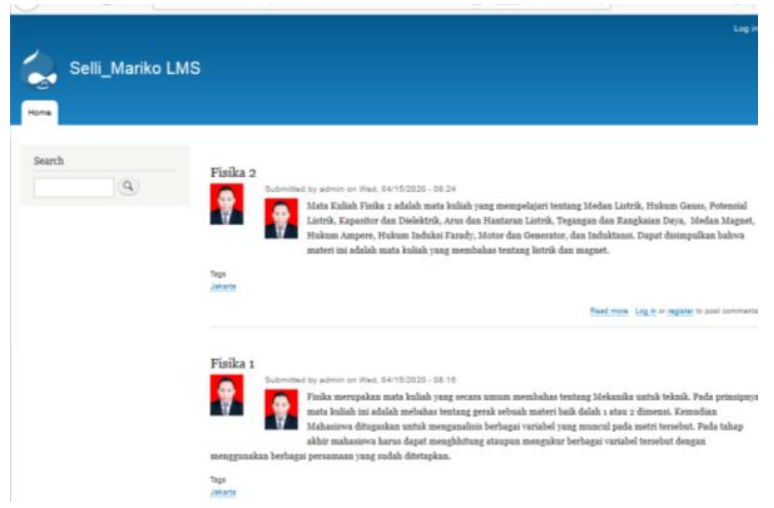

Gambar 3. Homepage e-Learning portal

Gambar 3 menampilkan halaman depan atau Homepage dari portal eLearning yang dikembangkan dengan Drupal CMS. Halaman awal berisi semua daftar mata kuliah yang diampu oleh Dosen beserta deskripsi mata kuliah. Pada setiap materi disajikan tautan untuk mengakses materi, penugasan dan link untuk menambah materi dari berbagai website yang mendukung perkuliahan. Selain itu disajikan forum tanya jawab dengan cara submit comment and reply untuk memberikan feedback atas pertanyaan seputar materi perkuliahan.

Untuk memudahkan pengelolaan mahasiswa, maka setiap mahasiswa yang akan akan mengikuti perkuliahan harus memiliki akun terlebih dahulu. Pada bagian bawah kanan setiap mata kuliah terdapat tautan login or register. Tautan login berfungsi untuk masuk ke portaleLearningdan mengakses perkuliahan bagi mahasiswa yang sudah memiliki akun. Sedangkan bagi mahasiswa yang belum memiliki akun dapat melakukan registrasi terlebih dahulu dengan melakukan klik pada link register. Pada halaman registrasi untuk membuat akun mahasiswa selanjutnya dapat dilihat pada Gambar 4. 
Mahasiswa diwajibkan untuk mengisi form yang tersedia kemudian melakukan konfirmasi akun dengan klik link verifikasi yang terkirim ke email. Untuk selanjutnya mahasiswa yang sudah registrasi dan memiliki akun dapat mengakses materi perkuliahan dengan melakukan login pada portal e-Learning.

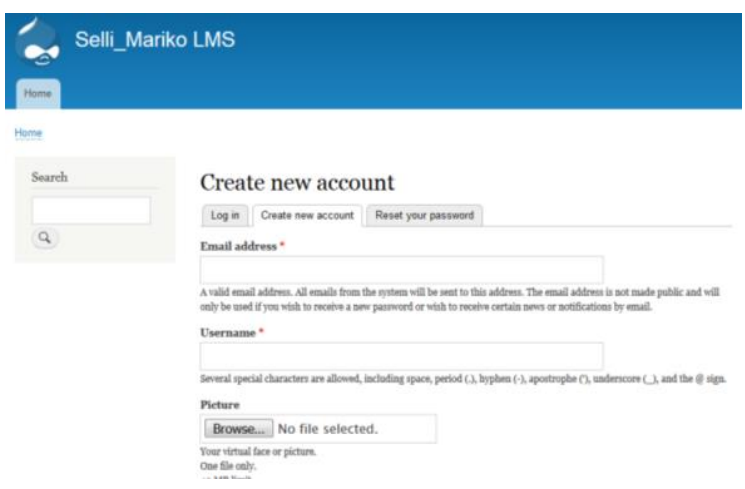

Gambar 4. Halaman registrasi akun baru

Ada beberapa alas an yang menjadi bahan pertimbangan penulis memilih Drupal CMS untuk membangun portal $e$ Learning. Hal ini dikarenakan terdapat keunggulan Drupal CMS dari pada open source CMS yang lain, diantaranya:

1. Mudah untuk digunakan karena tampilannya yang sederhana.

2. Memiliki performa yang dapat diandalkan karena tidak terlalu banyak fitur yang disematkan sehingga cepat untuk diakses.

3. Memiliki tingkat keamanan yang baik.

4. Fleksibel dan bersifat modular karena content yang diisikan tidak hanya masalah pendidikan saja akan tetapi dapat berupa informasi dan lain sebagainya.

5. Bersifat open source sehingga memberi kemudahan bagi user untuk mengunduh dan memasang aplikasi tanpa harus membayar lisensi.

Sesuai dengan metodologi penelitian yang digunakan pada riset/ penelitian ini. Setelah selesai dirancang portal e-Learning maka dilakukan analisis yang melibatkan user. Tujuannya adalah meminta user dalam hal ini adalah mahasiswa untuk memberikan masukan terkait prototype portal e-Learning yang sedang dikembangkan. Kegiatan ini terus dilakukan secara berulang oleh peneliti sampai user/ mahasiswa puas dan tidak ada lagi kesulitan dalam menggunakan/ mengakses semua fitur yang tersedia pada portal e-Learning.

Variabel yang dianalisis terkait dengan portal e-Learning meliputi: Aksesibilitas, Manfaat dan Motivasi. Kegiatan tersebut dilakukan untuk melihat apakah portal e-Learningy ang sudah dirancang dapat layak digunakan dalam menunjang kegiatan perkuliahan selama masa lockdown karena pandemi Covid-19. Jumlah user atau pengguna yang menggunakan portal e-Learning lebih dari 100 orang. Dikarenakan keterbatasan waktu dan tenaga, maka peneliti mengambil sampel dari populasi tersebut. Sampel yang digunakan representatif terhadap populasi. Pada kegiatan analisis dilakukan pengambilan data terhadap 30 orang mahasiswa secara acak/random sampling dari beberapa kelas. Apapun hasil yang didapatkan pada sampel maka akan berlaku pada seluruh populasi yang ada.

Hasil olah data kuantitatif yang dilakukan pada 30 sampel setelah dikonversi menjadi data kualitatif dapat diinterpretasikan pada Tabel 2.

Tabel 2. Konversi analisis data penelitian

\begin{tabular}{lcc}
\hline \multirow{2}{*}{ Variabel } & \multicolumn{2}{c}{ Kategori } \\
& Rendah & Tinggi \\
\hline Aksesibilitas & 3 & 27 \\
Manfaat & 4 & 26 \\
Motivasi & 6 & 24 \\
\hline
\end{tabular}

Pada variabel aksesibilitas 27 orang masuk kategori tinggi. Hal ini mengindikasikan bahwa $90 \%$ user atau mahasiswa menyatakan bawa portal e-Learning memiliki tingkat aksesibilitas yang baik. Hal ini dikarenakan fitur yang disematkan pada portal e-Learning hanya fitur yang 
mendukung perkuliahan saja. Sehingga untuk membuka portal e-Learning tidak memerlukan transfer data yang banyak Selain itu tampilan dibuat sederhana supaya user lebih mudah menggunakannya. Masih mengacu pada Tabel 2, untuk variabel manfaat terdapat 26 orang masuk pada kategori tinggi. Hal ini mengindikasikan bahwa $86,67 \%$ user atau mahasiswa menyatakan bahwa portal e-Learning ini bermanfaat dalam mendukung perkuliahan selama wabah pandemi Covid-19. Untuk variabel yang terakhir yaitu motivasi belajar menggunakan sistem $e$-Learning, mengacu data yang terdapat pada tabel 2 terdapat 24 orang masuk dalam kategori tinggi. Hal ini menunjukkan bahwa $80 \%$ user atau mahasiswa termotivasi dengan adanya portal e-Learning. Supaya mahasiswa termotivasi dalam menggunakan sistem $e$ Learning peneliti membuat link untuk tambahan materi, misalnya ke youtube atau link ke jurnal ilmiah.

Peran utama seorang dosen dalam. mengajar di kelas memang tidak dapat tergantikan. Proses transfer ilmu pengetahuan dan teknologi paling baik apabila dilakukan interaksi secara langsung antara dosen dan mahasiswa. Berbagai hasil riset yang dilakukan oleh peneliti menunjukkan sistem pembelajaran online dengan menggunakan portal e-Learning memang tidak dapat digunakan untuk meningkatkan hasil belajar secara signifikan. Hal ini senada dengan yang disampaikan oleh Islamiyah \& Widayanti (2016:45) menyatakan data hasil penelitian yang menunjukkan bahwa metode pembelajaran e-Learning berbasis website kurang efektif meningkatkan hasil belajar mahasiswa. Selain itu, hasil olah data menunjukkan bahwa hasil belajar siswa pada pokok bahasan rangkaian listrik menggunakan pembelajaran yang memanfaatkan e-Learningtidak lebih baik dibandingkan dengan yang menggunakan metode konvensional.

Sistem perkuliahan berbasis daring menggunakan portal $e$-Learning tidak dapat digunakan untuk meningkatkan hasil belajar secara signifikan, akan tetapi sistem ini sangat efektif untuk menggantikan perkuliahan. Apalagi ditambah adanya wabah pandemi Covid-19 yang tidak memungkinkan perkuliahan tatap muka di kelas. Dosen tetap dapat melakukan interaksi dengan mahasiswa, seperti: Memberikan materi kuliah, memberikan penugasan bahkan pengumpulan tugas. Hal ini senada dengan yang disampaikan oleh Khairunnisa dkk (2015:5) pada penelitian yang bertujuan untuk mengetahui efektivitas penggunaan portal e-Learning dalam kegiatan perkuliahan, maka hasil penelitiannya menunjukkan bahwa penggunaan e-Learning pada materi keperawatan bencana dasar sudah efektif. Hal ini dikarenakan sebagian besar mahasiswa menyukai proses pembelajaran menggunakan e-Learning. Selain itu mahasiswa merasakan berbagai fitur yang memberi kemudahan dalam mengakses materi yang akan dipelajari sehingga pada saat proses belajar mengajar berlangsung, mereka telah memperoleh informasi tentang materi yang akan dipelajari. Berdasarkan persentase rerata yang diperoleh sebesar $78,67 \%$ penggunaan e-Learningefektif untuk menunjang pembelajaran.

Kunci utama meraih keberhasilan perkuliahan menggunakan sistem $e$ Learning adalah dosen harus dapat menjadi fasilitator yang baik dalam mendampingi mahasiswa pada saat belajar. Selain itu dosen juga harus dapat membantu mahasiswa mengatasi kesulitan belajar melalui metode perkuliahan secara online dengan memberikan feedback secara 
langsung. Menurut Kusmana (2011:49) proses belajar mandiri mengubah peran dosen, guru, atau instruktur, menjadi fasilitator atau perancang proses belajar. Sebagai seorang fasilitator, seorang dosen, guru atau instruktur membantu peserta didik mengatasi kesulitan belajar. Selain itu dosen harus dapat menjadi mitra belajar untuk materi tertentu pada program tutorial. Oleh karena itu seorang dosen harus mampu mengolah materi ke dalam format sesuai dengan pola belajar mandiri.

Suksesnya aktivitas perkuliahan secara online di tengah wabah pandemi Covid-19, penulis sebagai dosen pengampu mata kuliah membuat beberapa kiat khusus. Pertama memberikan link materi tambahan di luar materi utama supaya lebih menarik dan memperluas wawasan mahasiswa. Kedua, membuat tampilan portal $e$ Learning sederhana tapi memberikan fungsi yang maksimal untuk mendukung perkuliahan online, karena semakin banyak fitur maka dibutuhkan bandwidth yang besar untuk mengaksesnya. Ketiga, durasi dan kuantitas dosen pada waktu untuk online lebih banyak sehingga dapat memberikan umpan balik kepada mahasiswa lebih cepat apabila terjadi kesulitan yang dialami oleh mahasiswa. Hal ini diperkuat oleh pendapat dari Mason \& Rennie (2010: 35) ada tiga kriteria utama yang dapat menentukan suksesnya komunitas untuk belajar secara online:

1. Self-Generated Evolution, anggota komunitas menghasilkan dan membangkitkan sendiri konten untuk situsnya dan mengambil keputusan bersama untuk mempengruhi pertumbuhan, adaptasi dan evolusinya.

2. Involvement and Interactivity, keterlibatan dan interaktivitas bagaimana anggota komunitas berpartisipasi dan berinteraksi satu dengan yang lainnya.

3. Frekuensi dan durasi kunjungan,yang mendorong anggota untuk dating kembali berulang-ulang untuk berbagi ide antar anggota komunitas sebagai bagian dari proses pembentukan identitas kolektif dan rasa kepercayaan antar anggota.

\section{KESIMPULAN DAN SARAN}

Mengacu pada tujuan penelitian dan hasil pembahasan, maka peneliti dapat menyimpulkan:

1. Sudah dibangun sistem perkuliahan onlineberupa portal e-Learning menggunakan Drupal CMS via jaringan internet untuk menggantikan perkuliahan tatap muka di kelas.

2. User/ mahasiswa sudah merasa cukup puas dan termotivasi dalam perkuliahan menggunakan portal e-Learning karena mereka dapat mengakses materi, mengumpulkan tugas dan mengikuti ujian menggunakan online test yang diberikan oleh dosen pengampu mata kuliah.

3. Kegiatan perkuliahan dapat tetap berjalan di masa pandemi Covid-19, sehingga dosen dapat menuntaskan materi perkuliahan sesuai target waktu yang ditentukan.

4. Hubungan antara dosen dan mahasiswa tetap terjalin tanpa ada batasan ruang dan waktu dimasa pandemi Covid-19, baik secara synchronous/komunikasi online langsung maupun asynchronous.

Adapun saran yang dapat penulis sampaikan untuk perbaikan dan bahan kajian penelitian selanjutnya diantaranya adalah: 
1. Pengembangan portal e-Learningk e depannya lebih luas mencakup semua materi yang ada di semua Program Studi Institusi pendidikan.

2. Portal e-Learning dapat masuk ke dalam subdomain dari domain yang dimiliki oleh lembaga sehingga tidak membebankan dosen.

3. Perlu adanya peran dari semua dosen untuk membuat materi dalam bentuk digital supaya dapat diunggah menjadi konten portal e-Learning.

4. Pemanfaatan portal e-Learning tidak hanya digunakan untuk mendukung perkuliahan pada saat pandemi Covid19 tetapi sudah menjadi trending dan kegiatan rutin untuk mendukung perkuliahan tatap muka di kelas.

\section{DAFTAR PUSTAKA}

Courts, B. \& Tucker, J. (2012). Using Technology To Create A Dynamic Classroom Experience. Journal of College Teaching \& Learning, 09(02), 121-128.

Fatta, H. A. (2007). Analisis dan Perancangan Sistem Informasi Untuk Keunggulan Bersaing Perusahaan dan Organisasi Modern. Yogyakarta: Penerbit ANDI.

Horton, W. (2006). e-Learning By Design. San Francisco: Pfeiffer A Wiley Imprint.

Islamiyah, M. \& Widayanti, L. (2016). Efektifitas Pemanfaatan eLearning Berbasis Website Terhadap Hasil Belajar Mahasiswa STMIK Asia Malang Pada Mata Kuliah Fisika Dasar. Jurnal Ilmiah Teknologi dan Informasia ASIA, 10(01), 41-46.
Jaya, I. (2019). Penerapan Statistik Untuk Penelitian Pendidikan. Jakarta: PRENADA GROUP.

Khairunnisa, A. dkk. (2015). Efektivitas Penerapan Model e-Learning Pada Materi Keperawatan Bencana Dasar Sekolah Tinggi Ilmu Kesehatan Harapan Bangsa Banda Aceh. Jurnal Ilmu Kebencanaan (JIKA), 02(03), 1-8.

Khazaal, H.F. et all. (2014). e-Learning And Instructional Management System Based On Local Computer Networks And Internet. Journal of College Teaching \& Learning, 11(03), 115-133.

Kusmana, A. (2011). e-Learning Dalam Pembelajaran. Jurnal Ilmu Tarbiyah dan Keguruan Lentera Pendidikan, 14(01), 35-51.

Littlejohn, A. \& Pegler, C. (2007). Preparing for Blended e-Learning. New York: Routledge Taylor and Francis Group.

Mason, R. \& Rennie, F. (2010). e-Learning Panduan Lengkap Memahami Dunia Digital dan Internet. Yogyakarta: Pustaka Baca.

Prawiradilaga, D.S., dkk. (2016). Mozaik Teknologi Pendidikan e-Learning. Jakarta: Prenadamedia Group.

Shandyastini, N.M. \& Novianti, K.D.P. (2016). Analisis e-Learning STMIK STIKOM Bali Menggunakan Techonology Acceptance Model. Jurnal Teknoif, 04(02), 1-6. 